Doi: HTTPS://DOI.ORG/10.23910/IJBSM/2017.8.6.3C0341

\title{
Genetic Analysis of Yield Contributing Traits in Lowland Rice Genotypes under Acidic Soils
}

\author{
Ashim Debnath, Mayank Rai*, Wricha Tyagi and Sudip Das
}

School of Crop Improvement, College of Post-Graduate Studies, Central Agricultural University (Imphal), Umiam, Meghalaya (793 103), India

\section{Corresponding Author}

Mayank Rai

e-mail: mrai.cau@gmail.com

\author{
Article History \\ Article ID: 3 C0341 \\ Received in $5^{\text {th }}$ October, 2017 \\ Received in revised form $19^{\text {th }}$ November, 2017 \\ Accepted in final form $5^{\text {th }}$ December, 2017
}

\begin{abstract}
Five cultivars adapted to the lowland acidic soils of the North Eastern Hill Region were crossed with three elite varieties that are not grown in the region, in a linextester design, in order to study their combining ability with respect to yield contributing traits under acidic lowland soils of Meghalaya. The performance of parents was also evaluated under aluminium toxic hydroponics conditions. Genetic analysis revealed locally adapted cultivars Priya and Sahbhagi Dhan to be the best general combiners, while among the testers, IR 24 and Kasalath showed the best general combining ability (GCA). Individual crosses Sahbhagi Dhan×Kasalath, Shahsarang×Samba Mahsuri SUB1, PriyaxIR 24 showed the best specific combining ability (SCA). The most prominent specific cross was Sahbhagi Dhan $\times$ Kasalath, which showed the highest heterotic value when compared against the best commercial cultivar of the region (Shahsarang) with respect to majority of the traits studied. The GCA of the tester Kasalath was highest for all the traits, whereas line Sahbhagi Dhan showed highest GCA for biological yield, grain yield and harvest index. The study suggests that segregating populations of cross Sahbhagi Dhan×Kasalath would be ideal for selection of high yielding transgressive segregants adapted to acidic soils. Hydroponic screening under aluminium toxic condition revealed BoroDhan and Shasarang to be the most tolerant parents as they accumulated high root and shoot biomass. These lines can be used as donors in breeding programmes aimed at enhancing tolerance to aluminium toxicity under acidic soils.
\end{abstract}

Keywords: Combining ability, acidic soil, Rice, aluminium toxicity

\section{Introduction}

Rice remains the staple food of more than half the world population and supplies up to $60 \%$ of the calories in the diet of people living in Asia. World rice demand is predicted to increase at about 1\% per year from 2001 to 2025, which is roughly equal to population growth in Asia during that period (Maclean et al., 2002). In India, 49 mha of land is affected by soil acidity of which 24 mha have a pH below 5.5 (Mandal, 1997). More than 95\% area in the North-Eastern region of India is affected by soil acidity (Sharma and Singh, 2002). Different agronomical practices are followed to reduce the above problems in acid soils. Liming has been used extensively to increase the $\mathrm{pH}$ of acidic soils, but it remains a costly, difficult and unsustainable option. So developing varieties which are inherently tolerant to such problems is the best approach for increasing the productivity of rice. Breeding strategies based on selection of hybrids require expected level of heterosis as well as the specific combining ability.

Analysis of combining ability is one of the powerful tools which helps in estimating the combining ability effects and aids in selecting the desirable parents and crosses for the exploitation of heterosis (Muhammad et al., 2007). Breeding strategies based on hybrid production require a high level of heterosis as well as the specific combining ability (SCA) of crosses. One of the main objectives of plant breeders for developing high yielding varieties is to select good parents and crosses (Rahimi et al., 2010). Plant breeders aim to identify parental lines with good general combining ability (GCA), and crosses showing high specific combining ability in a hybrid breeding program. Heterosis in rice was first reported by Jones (1926) who observed a marked increase in culm number and grain yield in some $F_{1}$ hybrids in comparison to their parents. Both positive and negative heterosis is useful in crop improvement, depending on the breeding objectives. Linextester analysis has effectively employed to identify suitable parents based on SCA and GCA effects (Singh and Kumar, 2004).

Under field conditions, several deficiencies and toxicities often co-exist, and it becomes difficult to partition the effect of different nutrient stresses on the genotypes. Therefore, especially for molecular biological studies, screening genotypes in artificial hydroponics conditions allows us to dissect the response of a genotype to one particular nutrient toxicity or deficiency. Since the forms of soil aluminum (Al) and their solubilities are high at a $\mathrm{pH}$ of 5 or less, aluminum toxicity becomes one of the major growths limiting factors 
affecting plants on acid soil (Kochian, 1995). Rice was found significantly more tolerant than maize, wheat and sorghum at all concentration in hydroponic experiment, they also demonstrated that high level of rice Al tolerance are mediated by a novel mechanism, which is independent of root tip Al exclusion (Famoso et al., 2010). The most recognized physiological mechanism conferring $\mathrm{Al}$ tolerance in plants involves exclusion of Al from the root tip (Kochian et al., 2004). Classical breeding procedures along with screening of genotypes to aluminium using hydroponics can then be employed for identification and utilization of superior genotypes to improve rice productivity under unfavourable environments such as lowland acidic soils. This information and understanding on genotypes and genetic resources would help in increasing rice productivity under lowland acidic soil conditions of the North Eastern Region of India. The present study was conducted on aset of eight promising genotypes for determining their combining ability under lowland acidic soil conditions, and aluminium toxicity tolerance under hydroponic condition.

\section{Materials and Methods}

\subsection{Study site}

A set of lowland rice (Oryza sativa) genotypes were germinated in CPGS, Umiam, Meghalaya, situated at latitude of $25^{\circ} 41^{\prime}$ and longitude of $91^{\circ} 54^{\prime}$ and an elevation of 950 $\mathrm{m}$ above mean sea level under controlled conditions for staggered planting in pots to match the flowering days of the testers which help in crossing when appropriate flowering time occurs. The genotypes taken in this particular study are given in Table 1.

\begin{tabular}{|c|c|c|}
\hline SI. No. & Code & Name of genotype \\
\hline 1. & $\mathrm{~L}_{1}$ & Priya \\
\hline 2. & $L_{2}$ & Paijang \\
\hline 3. & $\mathrm{~L}_{3}$ & Boro Dhan \\
\hline 4. & $\mathrm{~L}_{4}$ & Shahsarang \\
\hline 5. & $\mathrm{~L}_{5}$ & Sahbhagi Dhan \\
\hline 6. & $\mathrm{~T}_{1}$ & IR 24 \\
\hline 7. & $\mathrm{~T}_{2}$ & Sambha Mahsuri SUB1 (SMS) \\
\hline 8. & $\mathrm{~T}_{3}$ & KASALATH \\
\hline
\end{tabular}

\subsection{Experiments}

\subsubsection{LxT experiment}

The $F_{1}$ seeds were obtained by crossing the selected rice genotypes with the testers. In this study, five lines and three testers were used. Thus, the total numbers of $F_{1}$ genotypes obtained were 15 , the $F_{1}$ seedlings were transplanted into the field in randomized block design. The parents and their crosses were randomized and replicated thrice, once in each block and data was taken for no. of tillers plant ${ }^{-1}$, days to $50 \%$ flowering, no. of panicles plant ${ }^{-1}$, no. of grains panicle $e^{-1}$,grain yield plant ${ }^{-1}$, plant height, biological yield plant ${ }^{-1}, 100$ grain weight, \% spikelet fertility, panicle length, harvest index on ten plants in each treatment. Data were subjected to Analysis of Variance (ANOVA) followed by estimation of GCA, SCA and heterosis. Statistical analysis was conducted using Statistical Package for Agricultural Research (SPAR) 2.0. The obtained values of GCA, SCA and heterosis were tested for significance by comparing the calculated $t$ value with the tabulated $t$ value at both $0.1 \%$ and $0.5 \%$ level of significance.

\subsubsection{Hydroponic experiment}

All the genotypes used in the linextester analysis were selected for screening their ability to withstand Al toxicity which is a common abiotic stress in acidic soils. The seeds of the above selected genotypes were germinated in petri plates containing double moist filter paper and kept under controlled conditions in seed germinator. Once the seeds were germinated after five days they were transferred to plastic cupswhen sufficient root and shoot growth was observed. From each genotype 8 seedlings were put on styrofoams by making holes on it and stapled with net for support. These styrofoams were put into the cups i.e., two for control and two for treatment containing Magnavaca's nutrient solution (Magnavaca et al., 1987). The composition of this solution is as follows:

\begin{tabular}{|c|c|c|}
\hline Stock & Component & 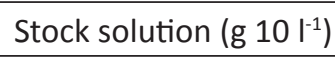 \\
\hline Stock 1 & $\mathrm{KCl}$ & 645.5 \\
\hline Stock 2 & $\mathrm{NH}_{4} \mathrm{NO}_{3}$ & 1200.6 \\
\hline Stock 3 & $\mathrm{CaCl}_{2}-2 \mathrm{H}_{2} \mathrm{O}$ & 1470.2 \\
\hline Stock 4 & $\mathrm{KH}_{2} \mathrm{PO}_{4}$ & 61.25 \\
\hline \multirow[t]{3}{*}{ Stock 5} & $\mathrm{MgSO}_{4}\left(7 \mathrm{H}_{2} \mathrm{O}\right)$ & 492.96 \\
\hline & $\mathrm{Mg}\left(\mathrm{NO}_{3}\right) 2\left(6 \mathrm{H}_{2} \mathrm{O}\right)$ & 1282.05 \\
\hline & $\mathrm{MgCl}_{2}\left(6 \mathrm{H}_{2} 0\right)$ & 315.43 \\
\hline \multirow[t]{5}{*}{ Stock 6} & $\mathrm{MnCl}_{2} 4 \mathrm{H}_{2} \mathrm{O}$ & 23.35 \\
\hline & $\mathrm{H}_{3} \mathrm{BO}_{3}$ & 20.4 \\
\hline & $\mathrm{ZnSO}_{4} 7 \mathrm{H}_{2} \mathrm{O}$ & 0.879 \\
\hline & $\mathrm{CuSO}_{4} 5 \mathrm{H}_{2} \mathrm{O}$ & 1.997 \\
\hline & $\mathrm{Na} 2 \mathrm{M}_{0} 02 \mathrm{H}_{2} \mathrm{O}$ & 2.588 \\
\hline Stock 7 & Fe-HEDTA & 0.283 \\
\hline
\end{tabular}

Stock solution 5 and 6 were dissolved separately and then the volume is made up to $10 \mathrm{~L}$ with distilled water. The aluminium toxic solution was made exactly the same way as the control Magnavaca solution but with the addition of aluminium chloride $(540 \mu \mathrm{M})$. Data were recorded on the seedlings which were grown in both the control and treatment cups containing the Magnavaca solution (after 21 days of growth) for root biomass, shoot biomass, plant height along with photos. 


\section{Results and Discussion}

Data of three replications of each individual trait were subjected to ANOVA, the results of which are given in Table 2. It was found that variances due to treatment, crosses and line $x$ tester were found to be significant for all the ten traits. Parents vs. Crosses also show significant result in all the nine traits except harvest index. Highly significant differences among the genotypes for all the yield contributing characters were showed which revealed wide range of variability for the genotypes. The mean sum of square due to lines were non significant for all the characters except plant height. The mean sum of square due to testers was observed highly significant for plant height, spikelet fertility, test weight, grain yield plant ${ }^{-1}$ and harvest index. The variances due to linextester interaction were highly significant for all the characters.

\begin{tabular}{lccccccccccc}
\hline \multicolumn{1}{l}{\begin{tabular}{l} 
Table 2: Analysis of variance for linextester analysis \\
\hline $\begin{array}{l}\text { Source of } \\
\text { variation }\end{array}$
\end{tabular} df } & TPP30 & TPP60 & PH & DTF & PPP & SF & TW & BY & GYPP & HI \\
\hline Replications & 2 & $9.44^{* *}$ & $7.59^{* *}$ & 29.03 & $3.17^{*}$ & $13.20^{* *}$ & 8.27 & 0.04 & 171.55 & $45.69^{*}$ & $0.02^{*}$ \\
Treatments & 22 & $9.43^{* *}$ & $14.63^{* *}$ & $351.86^{* *}$ & $31.55^{* *}$ & $12.23^{* *}$ & $1838.94^{* *}$ & $0.71^{* *}$ & $836.19^{* *}$ & $221.35^{* *}$ & $0.07^{* *}$ \\
Parents & 7 & 1.23 & $9.83^{* *}$ & $202.47^{* *}$ & $40.18^{* *}$ & $17.37^{* *}$ & $2942.64^{* *}$ & $0.73^{* *}$ & $226.75^{* *}$ & $122.49^{* *}$ & $0.12^{* *}$ \\
P. vs. C. & 1 & $143.10^{* *}$ & $132.03^{* *}$ & $3240.12^{* *}$ & $99.35^{* *}$ & $59.78^{* *}$ & $2906.68^{* *}$ & $0.66^{* *}$ & $7450.66^{* *}$ & $790.08^{* *}$ & 0.01 \\
Crosses & 14 & $3.98^{* *}$ & $8.65^{* *}$ & $220.25^{* *}$ & $22.40^{* *}$ & $6.27^{* *}$ & $1210.82^{* *}$ & $0.71^{* *}$ & $668.46^{* *}$ & $230.16^{* *}$ & $0.05^{* *}$ \\
Lines & 4 & 1.31 & 6.83 & $458.36^{* *}$ & 27.08 & 2.63 & 1086.19 & 0.71 & 154.02 & 110.9 & 0.03 \\
Testers & 2 & 5.24 & 3.73 & $296.80^{*}$ & 11.82 & 2.52 & $3060.09^{*}$ & $1.96^{*}$ & 570.60 & $635.21^{*}$ & $0.13^{*}$ \\
Linextester & 8 & $4.99^{* *}$ & $10.79^{* *}$ & $82.06^{*}$ & $22.71^{* *}$ & $9.03^{* *}$ & $810.81^{* *}$ & $0.39^{* *}$ & $950.15^{* *}$ & $188.52^{* *}$ & $0.04^{* *}$ \\
EMS & 44 & 1.29 & 1.32 & 35.12 & 0.69 & 2.16 & 58.31 & 0.12 & 65.40 & 14.94 & 0.01 \\
Grand mean & & 5.74 & 9.14 & 88.22 & 94.57 & 8.17 & 55.23 & 2.30 & 47.93 & 12.99 & 0.27 \\
\hline
\end{tabular}

Values given in the table are Mean Sum of Squares (MSS); *: Significant at $(p=0.05)$ level of significant ; ${ }^{* *}$ : Significant at $(p=0.01)$ level of significant

\subsection{Combining ability and heterosis}

\subsubsection{General combining ability}

Positive GCA effects were observed in all genotypes for all traits except days to $50 \%$ flowering and plant height where negative GCA effects were desirable. None of the lines or testers (pollinators) was found to be good general combiner for all the traits studied (Table 3). Positive significant GCA effects for grain yield per plant were exhibited by parents Sahbhagi Dhan, IR 24 and Kasalath. Thus the parents Sahbhagi Dhan, IR 24 and Kasalath were identified as good combiners for grain yield per plant. Among the lines, Sahbhagi Dhan was identified as a good general combiner for grain yield plant ${ }^{-1}$ along with some other characters viz., days to $50 \%$ flowering, spikelet fertility, biological yield and harvest index. Among the testers, Kasalath was identified as a good general combiner for grain yieldplant ${ }^{-1}$ along with some other characters viz., number of tillers plant ${ }^{-1}$ ( 30 days and 60 days after sowing), test weight, biological yield and harvest index.

\subsubsection{Specific combining ability}

For days to 50\% flowering and plant height negative SCA effects were desirable, whereas for other traits, positive SCA effects were desirable. None of the cross combinations was

Table 3: GCA effects of lines and testers

\begin{tabular}{lcccccccccc}
\hline Parents & TPP30 & TPP 60 & PH & DTF & PPP & SF & TW & BY & GYPP & HI \\
\hline $\mathrm{L}_{1}$ & -0.27 & $-1.19^{* *}$ & $-10.22^{* *}$ & $1.87^{* *}$ & -0.30 & $-6.36^{* *}$ & $0.29^{* *}$ & $-6.48^{* *}$ & $1.49^{*}$ & $0.06^{*}$ \\
$\mathrm{~L}_{2}$ & 0.48 & $0.66^{*}$ & $2.88^{* *}$ & $0.64^{* *}$ & $0.68^{*}$ & $-7.20^{* *}$ & -0.35 & $1.61^{*}$ & $-2.94^{* *}$ & $-0.06^{*}$ \\
$\mathrm{~L}_{3}$ & -0.46 & $0.95^{* *}$ & $-4.52^{* *}$ & $-2.69^{* *}$ & 0.49 & -10.22 & -0.25 & -1.02 & $-2.53^{* *}$ & -0.04 \\
$\mathrm{~L} 4$ & 0.26 & 0.12 & $5.48^{* *}$ & $0.76^{* *}$ & -0.41 & $10.60^{* *}$ & 0.16 & 1.29 & $-1.49^{*}$ & -0.03 \\
$\mathrm{~L}_{5}$ & -0.01 & -0.52 & $6.37^{* *}$ & $-0.58^{*}$ & -0.46 & $13.18^{* *}$ & 0.15 & $4.59^{* *}$ & $5.45^{* *}$ & $0.06^{* *}$ \\
$\mathrm{~T}_{1}$ & $-0.49^{*}$ & -0.12 & $-1.24^{*}$ & $-1.02^{* *}$ & -0.08 & $13.88^{* *}$ & $0.24^{* *}$ & $-2.87^{* *}$ & $1.79^{* *}$ & $0.04^{*}$ \\
$\mathrm{~T}_{2}$ & -0.16 & -0.42 & $-3.70^{* *}$ & $0.58^{* *}$ & -0.36 & $-14.65^{* *}$ & $-0.42^{* *}$ & $-4.21^{* *}$ & $-7.22^{* *}$ & $-0.11^{* *}$ \\
$\mathrm{~T}_{3}$ & $0.66^{* *}$ & $0.55^{*}$ & $4.94^{* *}$ & $0.44^{*}$ & 0.45 & 0.77 & $0.18^{*}$ & $7.08^{* *}$ & $5.42^{* *}$ & $0.07^{* *}$ \\
\hline
\end{tabular}

*: Significant at $(p=0.05)$ level of significance; **: Significant at $(p=0.01)$ level of significance 
observed to be a good cross combination for all the traits studied (Table 4). In our study hybrid (Priya X IR 24) recorded the highest grain yield plant ${ }^{-1}$ with significantly higher SCA effects for grain yield plant ${ }^{-1}$ and its components viz., effective tillers plant ${ }^{-1}$ ( 30 days and 60 days), plant height, days to $50 \%$ flowering, panicle plant ${ }^{-1}$, spikelet fertility, biological yield and harvest index. The other outstanding hybrids for grain yield plant $^{-1}$ were- (Sahbhagi Dhan×Kasalath) , having significant SCA effects for tillers plant ${ }^{-1}$ (30 days and 60 days), panicle plant ${ }^{-1}$, biological yield; and (Shahsarang X SMS), which showed significant SCA effects for grain yield plant ${ }^{-1}$, effective tillers panicle $^{-1}$, panicle plant ${ }^{-1}$, biological yield. Hybrid (Paijang X IR 24) showed significant SCA effects for spikelet fertility, grain yield plant $^{-1}$, and biological yield. Hybrid (Paijang X SMS) showed significant SCA effects for grain yield plant ${ }^{-1}$, biological yield, and effective tillers panicle ${ }^{-1}$ (30 days and 60 days). In

\begin{tabular}{|c|c|c|c|c|c|c|c|c|c|c|}
\hline Crosses & TPP30 & TPP 60 & $\mathrm{PH}$ & DTF & PPP & SF \% & TW & BY & GYPP & $\mathrm{HI}$ \\
\hline $\mathrm{L}_{1} \times \mathrm{T}_{1}$ & $0.97^{*}$ & $1.61^{* *}$ & -0.53 & -0.53 & $1.53^{* *}$ & $12.90^{* *}$ & $-0.41^{*}$ & $15.63^{* *}$ & $10.18^{* *}$ & $0.09^{*}$ \\
\hline $\mathrm{L}_{1} \times \mathrm{T}_{2}$ & -0.12 & 0.33 & $-3.13^{* *}$ & $-3.13^{* *}$ & 0.61 & $-28.63^{* *}$ & 0.25 & 1.40 & $-7.67^{* *}$ & $-0.18^{* *}$ \\
\hline $\mathrm{L}_{1} \times \mathrm{T}_{3}$ & $-0.85^{*}$ & $-1.94^{* *}$ & $3.67^{* *}$ & $3.67^{* *}$ & $-2.13^{* *}$ & $15.73^{* *}$ & 0.15 & $-17.03^{* *}$ & $-2.51^{* *}$ & $0.10^{*}$ \\
\hline $\mathrm{L}_{2} \times \mathrm{T}_{1}$ & 0.14 & -0.59 & 0.69 & $0.69^{*}$ & -0.12 & $10.64^{* *}$ & 0.12 & $4.38^{* *}$ & $5.09^{* *}$ & 0.07 \\
\hline $\mathrm{L}_{2} \times \mathrm{T}_{2}$ & $0.93^{*}$ & $1.40^{* *}$ & 0.09 & 0.09 & 0.63 & 0.23 & 0.16 & $10.71^{* *}$ & $2.69^{* *}$ & 0.01 \\
\hline $\mathrm{L}_{2} \times \mathrm{T}_{3}$ & $-1.06^{*}$ & $-0.81^{*}$ & -0.78 & $-0.78^{*}$ & -0.51 & $-10.87^{* *}$ & -0.28 & $-15.09^{* *}$ & $-7.79^{* *}$ & -0.08 \\
\hline $\mathrm{L}_{3} \times \mathrm{T}_{1}$ & 0.08 & -0.54 & $2.02^{*}$ & $2.02^{* *}$ & 0.01 & $-7.77^{* *}$ & -0.10 & $-3.41^{* *}$ & -0.26 & 0.02 \\
\hline $\mathrm{L}_{3} \times \mathrm{T}_{2}$ & -0.76 & $-1.12^{* *}$ & -0.58 & -0.58 & -0.65 & $15.49^{* *}$ & -0.02 & $-10.43^{* *}$ & $2.09^{* *}$ & 0.06 \\
\hline $\mathrm{L}_{3} \times \mathrm{T}_{3}$ & 0.68 & $1.66^{* *}$ & -1.44 & $-1.44^{* *}$ & 0.64 & $-7.73^{* *}$ & 0.12 & $13.84^{* *}$ & $-1.84^{*}$ & $-0.08^{*}$ \\
\hline $\mathrm{L}_{4} \times \mathrm{T}_{1}$ & $-0.89^{*}$ & -0.30 & $-2.76^{* *}$ & $-2.76^{* *}$ & $-1.73^{* *}$ & $-2.33^{* *}$ & $0.57^{* *}$ & $-14.80^{* *}$ & $-9.39^{* *}$ & $-0.10^{*}$ \\
\hline $\mathrm{L}_{4} \times \mathrm{T}_{2}$ & $1.44^{* *}$ & $1.61^{* *}$ & $4.31^{* *}$ & $4.31^{* *}$ & $1.72^{* *}$ & 0.83 & $-0.52^{* *}$ & $17.33^{* *}$ & $5.17^{* *}$ & 0.03 \\
\hline $\mathrm{L}_{4} \times \mathrm{T}_{3}$ & -0.54 & $-1.31^{* *}$ & -1.56 & $-1.56^{* *}$ & 0.01 & 1.50 & -0.05 & $-2.53^{* *}$ & $4.22^{* *}$ & 0.07 \\
\hline $\mathrm{L}_{5} \times \mathrm{T}_{1}$ & -0.29 & -0.16 & 0.58 & 0.58 & 0.31 & $-13.44^{* *}$ & -0.19 & $-1.81^{*}$ & $-5.63^{* *}$ & -0.07 \\
\hline$L_{5} \times T 2$ & $-1.48^{* *}$ & $-2.22^{* *}$ & -0.69 & $-0.69^{*}$ & $-2.30^{* *}$ & $12.08^{* *}$ & 0.13 & $-19.01^{* *}$ & $-2.28^{* *}$ & $0.08^{*}$ \\
\hline $\mathrm{L}_{5} \times \mathrm{T}_{3}$ & $1.78^{* *}$ & $2.39^{* *}$ & 0.11 & 0.11 & $1.99^{* *}$ & 1.36 & 0.06 & $20.82^{* *}$ & $7.91^{* *}$ & -0.01 \\
\hline
\end{tabular}

*: Significant at $(p=0.05)$ level of significance; **: Significant at $(p=0.01)$ level of significance

our study, crosses (PriyaxIR 24) and (Sahbhagi Dhan×Kasalath) were most promising for grain yield plant ${ }^{-1}$ and also with some important traits based on SCA effects.

Linextester is one of the most popular experimental breeding procedures for analyzing the combining ability of self pollinated crops like rice, which provides information about general combining ability (GCA) and specific combining ability (SCA) effects of parents and is helpful in estimating various types of gene actions. In this study, analysis was performed in acidic soils for five lines and three testers. The results are summarized in Table 6. Singh and Kumar (2004) also identified suitable parents through linextester analysis in rice. In the present study, among the lines Priya and Sahbhagi Dhan showed high GCA. Among the testers IR 24 and Kasalath showed good GCA for majority of the traits. Thus the resulting $\mathrm{F}_{1} \mathrm{~s}$ were no doubt the best performers as compared to the $F_{1} s$ which were obtained as a result from other cross combinations.

\subsubsection{Heterosis}

Relative heterosis, heterobeltiosis and standard heterosis manifested in the $\mathrm{F}_{1} \mathrm{~s}$ for all the traits were calculated (Table 5 , only better parent heterosis is shown). Both positive and negative heterosis is useful in crop improvement. In general positive heterosis is desired for yield and negative heterosis for early flowering and plant height (Nuruzzaman et al., 2002). The spectrum of variation for days to $50 \%$ flowering ranged from -8.78 to 6.24 for mid parent heterosis, -4.93 to 5.28 for standard heterosis and -5.59 to 7.58 for better parent heterosis or heterobeltiosis. In the case of plant height negative value was seen only in five crosses for standard heterosis. Hybrid cross between (Sahbhagi Dhan×Kasalath) showed highest heterosis value for tiller number plant ${ }^{-1}$ (both in 30 and 60 days old) and number of panicles plant ${ }^{-1}$. For mid parent and better parent heterosis, crosess (Sahbhagi Dhan $\times$ Kasalath) and (Paijang $\times$ SMS) were found to be superior with respect to grain yield plant ${ }^{-1}$. Hybrid cross (Paijang $\times \mathrm{SMS}$ ) also showed highest relative heterosis for the traits \% spikelet fertility and harvest index. For the traits test weight and biological yield, cross (Shahsarang $\times I R 24$ ) gives highest mid parent and standard heterotic value. It was found that hybrid (Sahbhagi Dhan×Kasalath) showed highest standard heterosis value for 


\begin{tabular}{|c|c|c|c|c|c|c|c|c|c|c|}
\hline Crosses & $\begin{array}{l}\text { No. of } \\
\text { tillers } \\
\text { plant }^{-1} \\
\text { (30 days) }\end{array}$ & $\begin{array}{l}\text { No. of } \\
\text { tillers } \\
\text { plant }^{-1} \\
\text { (60 days) }\end{array}$ & $\begin{array}{l}\text { Plant } \\
\text { height }\end{array}$ & $\begin{array}{c}\text { Days } \\
\text { to } 50 \% \\
\text { flowering }\end{array}$ & $\begin{array}{c}\text { No. of } \\
\text { panicles } \\
\text { plant }^{-1}\end{array}$ & $\begin{array}{l}\text { Percent } \\
\text { spikelet } \\
\text { fertility }\end{array}$ & $\begin{array}{c}100 \text { grain } \\
\text { weight }\end{array}$ & $\begin{array}{l}\text { Biologi- } \\
\text { cal Yield }\end{array}$ & $\begin{array}{l}\text { Grain } \\
\text { yield } \\
\text { plant }^{-1}\end{array}$ & $\begin{array}{l}\text { Harvest } \\
\text { index }\end{array}$ \\
\hline $\mathrm{L}_{1} \times \mathrm{T}_{1}$ & 46.09 & 16.39 & 14.63 & 2.92 & -4.76 & 33.26 & -10.91 & -10.91 & 51.89 & 153.07 \\
\hline$L_{1} \times T_{2}$ & 76.30 & 27.14 & 20.57 & 0.72 & 35.38 & -80.87 & -10.6 & 13.60 & -83.44 & -85.75 \\
\hline $\mathrm{L}_{1} \times \mathrm{T}_{3}$ & 68.89 & 21.39 & 14.85 & 3.46 & 5.64 & -10.55 & 1.18 & -3.95 & 58.93 & 52.10 \\
\hline $\mathrm{L}_{2} \times \mathrm{T}_{1}$ & 44.35 & 12.45 & 28.01 & 2.92 & -11.11 & 28.13 & -8.88 & 63.80 & 69.81 & 1.33 \\
\hline $\mathrm{L}_{2} \times \mathrm{T}_{2}$ & 127.06 & 43.66 & 53.40 & 2.89 & 42.03 & 68.67 & -17.8 & 136.45 & 774.12 & 188.20 \\
\hline $\mathrm{L}_{2} \times \mathrm{T}_{3}$ & 83.07 & 28.56 & 25.72 & -3.42 & 37.20 & -45.55 & -37.2 & 75.49 & 2.38 & -36.44 \\
\hline $\mathrm{L}_{3} \times \mathrm{T}_{1}$ & 23.60 & 2.88 & 14.59 & 0.73 & -11.75 & -7.39 & -28.3 & 0.19 & 26.56 & -8.41 \\
\hline $\mathrm{L}_{3} \times \mathrm{T}_{2}$ & 15.94 & -5.79 & 28.96 & -1.44 & -18.30 & 122.50 & -47.9 & -17.20 & 461.02 & 359.19 \\
\hline $\mathrm{L}_{3} \times \mathrm{T}_{3}$ & 64.29 & 31.30 & 30.33 & -5.59 & 2.28 & -45.40 & -22.9 & 56.68 & 66.62 & -32.88 \\
\hline $\mathrm{L}_{4} \times \mathrm{T}_{1}$ & 18.26 & 9.67 & 39.89 & -0.73 & -36.92 & 12.18 & 30.88 & -1.31 & -59.50 & -52.44 \\
\hline $\mathrm{L}_{4} \times \mathrm{T}_{2}$ & 124.46 & 61.23 & 43.29 & 7.58 & 34.25 & -22.48 & -32.7 & 76.30 & -24.25 & -55.98 \\
\hline $\mathrm{L}_{4} \times \mathrm{T}_{3}$ & 90.98 & 62.01 & 33.16 & -1.41 & 21.92 & -7.06 & -10.8 & 54.69 & 50.07 & -0.80 \\
\hline $\mathrm{L}_{5} \times \mathrm{T}_{1}$ & 25.22 & 4.09 & 29.09 & 1.46 & -17.84 & -0.09 & -16.6 & 54.87 & 18.38 & -46.89 \\
\hline $\mathrm{L}_{5} \times \mathrm{T} 2$ & 45.18 & 0.12 & 45.12 & 0.72 & 12.42 & -4.18 & -28.2 & 35.12 & -20.86 & -45.81 \\
\hline $\mathrm{L}_{5} \times \mathrm{T}_{3}$ & 145.93 & 114.02 & 45.60 & -6.64 & 112.42 & -3.95 & -10.1 & 214.48 & 137.41 & -32.67 \\
\hline
\end{tabular}

*: Significant at $(p=0.05)$ level of significance; **: Significant at $(p=0.01)$ level of significance

maximum of the traits-tiller plant ${ }^{-1}$ (30 days), tiller plant ${ }^{-1}$ (60 days), plant height, number of panicle plant ${ }^{-1}$, grain yield plant $^{-1}$ and harvest index.

A high percentage of heterosis for grain yield and its related traits and combining ability of hybrid rice were reported by Zhang et al. (2002). The specific combining ability (SCA) of this cross was also high for the same traits except 100 grain weight (gm) and harvest index. The general combining ability of the tester Kasalath was highest for all the traits showing highest heterotic value but in case of line $L_{5}$ highest gca was shown only for traits biological yield, grain yield (gm), harvest index. Bagheri and Jelodar (2010) reported in their studies that Variances of SCA were higher than the GCA variances for traits except for plant height which indicated predominance of non-additive gene action in the inheritance of the traits. The highest heterosis (106.60\%) was observed in cross IR 68899A PPoya followed by other eight crosses for yield and most of its related traits. The cross combinations IR 62829A ×Mosa-tarom, IR 68899A ×Poya, IR 58025A $\times$ IR 50 and IR 58025AxPoya were observed to be good specific cross combinations for grain yield and most of its related traits due to highly significant SCA and heterotic effects.

In the present study it was observed that the cross PriyaxIR 24 showed good SCA for six of the traits, although it did not show the highest value, but it did show a consistent overall performance based on the six traits as shown in the Table 6 .
One of the major factors being that one of its parents, Priya showed a good performance per se in majority of the traits, thus contributing to the consistency of the $F_{1}$. Also the GCA of both the parents was also good for majority of the traits, which may be another factor for the consistency of the $F_{1}$ in this case. This particular $F_{1}$ was also observed showing a significant heterotic value for three of the traits.

Hasan et al. (2013) observed similar findings and identified crosses BRRI 9A×BR 168R and D.ShanA×BR 168R were most promising for yield and desired traits based on SCA effects, per se performance and GCA effects of parents for grain yield and its components in rice which could be exploited beneficially in future rice breeding program by adopting heterosis breeding strategy.

Paijang $\times$ SMS showed very low heterosis value for traits grain yield per plant and harvest index. This may be due to the very low per se performance of $L_{2}$ and $T_{2}$ with respect to grain yield and harvest index under acidic soil without any soil amelioration.

\subsection{Hydroponics screening for aluminium toxicity}

The hydroponics experiment was conducted under greenhouse conditions, where each genotype tested was grown in individual plastic cups containing normal nutrient solution (control) and a solution containing $\mathrm{Al}$ in toxic amounts (Figure 1). The eight parental lines used in linextester analysis were evaluated under hydroponics condition for aluminium 


\begin{tabular}{|c|c|c|c|c|c|c|c|c|}
\hline \multirow[t]{2}{*}{ Traits } & \multicolumn{4}{|c|}{ Parents } & \multicolumn{3}{|c|}{ Crosses } & \multirow{2}{*}{$\begin{array}{l}\text { GCA of parents involved } \\
\text { in heterotic crosses }\end{array}$} \\
\hline & Perse & mance & & & $\begin{array}{l}\text { Per se per- } \\
\text { formance }\end{array}$ & SCA & Heterosis & \\
\hline $\begin{array}{l}\text { No. of tillers } \\
\text { plant }^{-1} \text { (30 days) }\end{array}$ & $\mathrm{L}_{3}$ & $\mathrm{~T}_{1}$ & $\mathrm{~L}_{2}$ & $\mathrm{~T}_{3}$ & $\mathrm{~L}_{5} \times \mathrm{T}_{3}$ & $\begin{array}{l}\mathrm{L}_{5} \times \mathrm{T}_{3} \\
\mathrm{~L}_{4} \times \mathrm{T}_{2} \\
\mathrm{~L}_{1} \times \mathrm{T}_{1}\end{array}$ & $\begin{array}{l}\mathrm{L}_{5} \times \mathrm{T}_{3} \\
\mathrm{~L}_{4} \times \mathrm{T}_{2} \\
\mathrm{~L}_{2} \times \mathrm{T}_{2}\end{array}$ & $\begin{array}{l}A / G \\
A / A \\
G / A\end{array}$ \\
\hline $\begin{array}{l}\text { No. of tillers } \\
\text { plant }^{-1} \text { ( } 60 \text { days) }\end{array}$ & $\mathrm{L}_{3}$ & $\mathrm{~T}_{1}$ & $\mathrm{~L}_{3}$ & $\mathrm{~T}_{3}$ & $\mathrm{~L}_{3} \times \mathrm{T}_{3}$ & $\begin{array}{l}\mathrm{L}_{5} \times \mathrm{T}_{3} \\
\mathrm{~L}_{3} \times \mathrm{T}_{3} \\
\mathrm{~L}_{1} \times \mathrm{T}_{1} \\
\mathrm{~L}_{4} \times \mathrm{T}_{2}\end{array}$ & $\begin{array}{l}\mathrm{L}_{3} \times \mathrm{T}_{3} \\
\mathrm{~L}_{5} \times \mathrm{T}_{3} \\
\mathrm{~L}_{2} \times \mathrm{T}_{2}\end{array}$ & $\begin{array}{l}G / G \\
A / G \\
A / P\end{array}$ \\
\hline $\begin{array}{l}\text { Plant height } \\
(\mathrm{cm})\end{array}$ & $\mathrm{L}_{5}$ & $\mathrm{~T}_{3}$ & $\mathrm{~L}_{1}$ & $\mathrm{~T}_{2}$ & $\mathrm{~L}_{1} \times \mathrm{T}_{2}$ & $\begin{array}{l}L_{1} \times T_{2} \\
L_{4} \times T_{1} \\
L_{4} \times T_{3}\end{array}$ & $\begin{array}{l}\mathrm{L}_{1} \times \mathrm{T}_{2} \\
\mathrm{~L}_{3} \times \mathrm{T}_{2} \\
\mathrm{~L}_{3} \times \mathrm{T}_{1}\end{array}$ & $\begin{array}{l}G / G \\
A / G \\
A / A\end{array}$ \\
\hline $\begin{array}{l}\text { Days to } 50 \% \\
\text { flowering }\end{array}$ & $\mathrm{L}_{5}$ & $\mathrm{~T}_{3}$ & $\mathrm{~L}_{3}$ & $\mathrm{~T}_{1}$ & $\mathrm{~L}_{3} \mathrm{XT}_{3}$ & $\begin{array}{l}L_{1} \times T_{2} \\
L_{4} \times T_{1} \\
L_{4} \times T_{3}\end{array}$ & $\begin{array}{l}\mathrm{L}_{3} \times \mathrm{T}_{3} \\
\mathrm{~L}_{4} \times \mathrm{T}_{1} \\
\mathrm{~L}_{3} \times \mathrm{T}_{2}\end{array}$ & $\begin{array}{l}G / A \\
A / G \\
G / P\end{array}$ \\
\hline $\begin{array}{l}\text { No. of panicles } \\
\text { per plant }\end{array}$ & $\mathrm{L}_{3}$ & $\mathrm{~T}_{1}$ & $\mathrm{~L}_{2}$ & $\mathrm{~T}_{3}$ & $\mathrm{~L}_{5} \times \mathrm{T}_{3}$ & $\begin{array}{l}L_{5} \times T_{3} \\
L_{4} \times T_{2} \\
L_{1} \times T_{1}\end{array}$ & $\begin{array}{l}\mathrm{L}^{\mathrm{S} \times \mathrm{T}_{3}} \\
\mathrm{~L}_{3} \times \mathrm{T}_{3} \\
\mathrm{~L}_{1} \times \mathrm{T}_{1}\end{array}$ & $\begin{array}{l}P / G \\
A / G \\
A / A\end{array}$ \\
\hline $\begin{array}{l}\% \text { spikelet } \\
\text { fertility }\end{array}$ & $L_{5}$ & $\mathrm{~T}_{3}$ & $\mathrm{~L}_{5}$ & $\mathrm{~T}_{1}$ & $\mathrm{~L}_{4} \times \mathrm{T} 1$ & $\begin{array}{l}\mathrm{L}_{1} \times \mathrm{T}_{3} \\
\mathrm{~L}_{3} \times \mathrm{T}_{2} \\
\mathrm{~L}_{1} \times \mathrm{T}_{1}\end{array}$ & $\begin{array}{l}\mathrm{L}_{4} \times \mathrm{T}_{1} \\
\mathrm{~L} 1 \times \mathrm{T}_{1} \\
\mathrm{~L}_{2} \times \mathrm{T}_{1}\end{array}$ & $\begin{array}{l}A / G \\
A / G \\
A / G\end{array}$ \\
\hline $\begin{array}{l}100 \text { grain } \\
\text { weight }(\mathrm{g})\end{array}$ & $\mathrm{L}_{3}$ & $\mathrm{~T}_{3}$ & $\mathrm{~L}_{1}$ & $\mathrm{~T}_{1}$ & $\mathrm{~L}_{4} \times \mathrm{T} 1$ & $\begin{array}{l}\mathrm{L}_{4} \times \mathrm{T}_{1} \\
\mathrm{~L}_{1} \times \mathrm{T}_{2} \\
\mathrm{~L}_{2} \times \mathrm{T}_{2}\end{array}$ & $\begin{array}{l}\mathrm{L}_{4} \times \mathrm{T}_{1} \\
\mathrm{~L}_{1} \times \mathrm{T}_{3} \\
\mathrm{~L}_{5} \times \mathrm{T}_{3}\end{array}$ & $\begin{array}{l}A / G \\
G / A \\
A / A\end{array}$ \\
\hline Biological Yield & $\mathrm{L}_{3}$ & $\mathrm{~T}_{1}$ & $\mathrm{~L}_{5}$ & $\mathrm{~T}_{3}$ & $\mathrm{~L}_{5} \times \mathrm{T}_{3}$ & $\begin{array}{l}L_{5} \times T_{3} \\
L_{4} \times T_{2} \\
L_{1} \times T_{1}\end{array}$ & $\begin{array}{l}\mathrm{L}_{4} \times \mathrm{T}_{1} \\
\mathrm{~L}_{1} \times \mathrm{T}_{3} \\
\mathrm{~L}_{5} \times \mathrm{T}_{3}\end{array}$ & $\begin{array}{l}A / A \\
P / G \\
G / G\end{array}$ \\
\hline Grain yield (gm) & $\mathrm{L}_{4}$ & $\mathrm{~T}_{1}$ & $\mathrm{~L}_{5}$ & $\mathrm{~T}_{3}$ & $\mathrm{~L}_{5} \times \mathrm{T}_{3}$ & $\begin{array}{l}\mathrm{L}_{1} \times \mathrm{T}_{1} \\
\mathrm{~L}_{5} \times \mathrm{T}_{3} \\
\mathrm{~L}_{4} \times \mathrm{T}_{2}\end{array}$ & $\begin{array}{l}\mathrm{L}_{5} \times \mathrm{T}_{3} \\
\mathrm{~L}_{3} \times \mathrm{T}_{3} \\
\mathrm{~L}_{4} \times \mathrm{T}_{2}\end{array}$ & $\begin{array}{l}G / G \\
A / G \\
A / P\end{array}$ \\
\hline Harvest index & $\mathrm{L}_{5}$ & $\mathrm{~T}_{3}$ & $\mathrm{~L}_{1} \mathrm{~L}_{5}$ & $\mathrm{~T}_{3}$ & $\mathrm{~L}_{1} \times \mathrm{T}_{3}$ & $\begin{array}{l}\mathrm{L}_{1} \times \mathrm{T}_{3} \\
\mathrm{~L}_{1} \times \mathrm{T}_{1} \\
\mathrm{~L}_{5} \times \mathrm{T}_{2}\end{array}$ & $\begin{array}{l}\mathrm{L} \times \mathrm{T}_{3} \\
\mathrm{~L}_{1} \times \mathrm{T}_{1} \\
\mathrm{~L}_{4} \times \mathrm{T}_{3}\end{array}$ & $\begin{array}{l}G / G \\
G / A \\
A / G\end{array}$ \\
\hline
\end{tabular}

G: Good; A: Average; P: Poor

toxicity. Magnavaca's nutrient solution with aluminium (under treatment) was used for screening the lowland genotypes. Root inhibition was seen in the treatment solution of all the genotypes depending upon their degree of tolerance. Data were taken after 21 days from the date of introducing the seedlings in Magnavaca's solution. There was significant decrease in shoot biomass and root biomass in almost all of the genotypes in treatment (540 $\mu \mathrm{M} \mathrm{Al}$ ) as compared to control (0 M Al). Parent Boro Dhan and Shasarang performed well as they showed relatively less reduction in shoot and root biomass under treatment condition as compared to control, where as Paijang and IR 24 performed poorly on the basis of shoot biomass and root biomass (Figure 2).

Aluminium toxicity under hydroponics conditions, in general leads to inhibition of root growth, specifically in case of lateral roots. Thickening of roots was also observed due to callose deposition in cell walls (Figure 3). Previously, Famoso et al. (2010) had performed Al toxicity screening for 400 O. sativas and two RIL populations using Magnavaca's nutrient solution. Kochian's group had previously shown that rice is not only most Al tolerant of all cereal crops but also shows tolerance by mechanisms distinct from those shown by maize and 

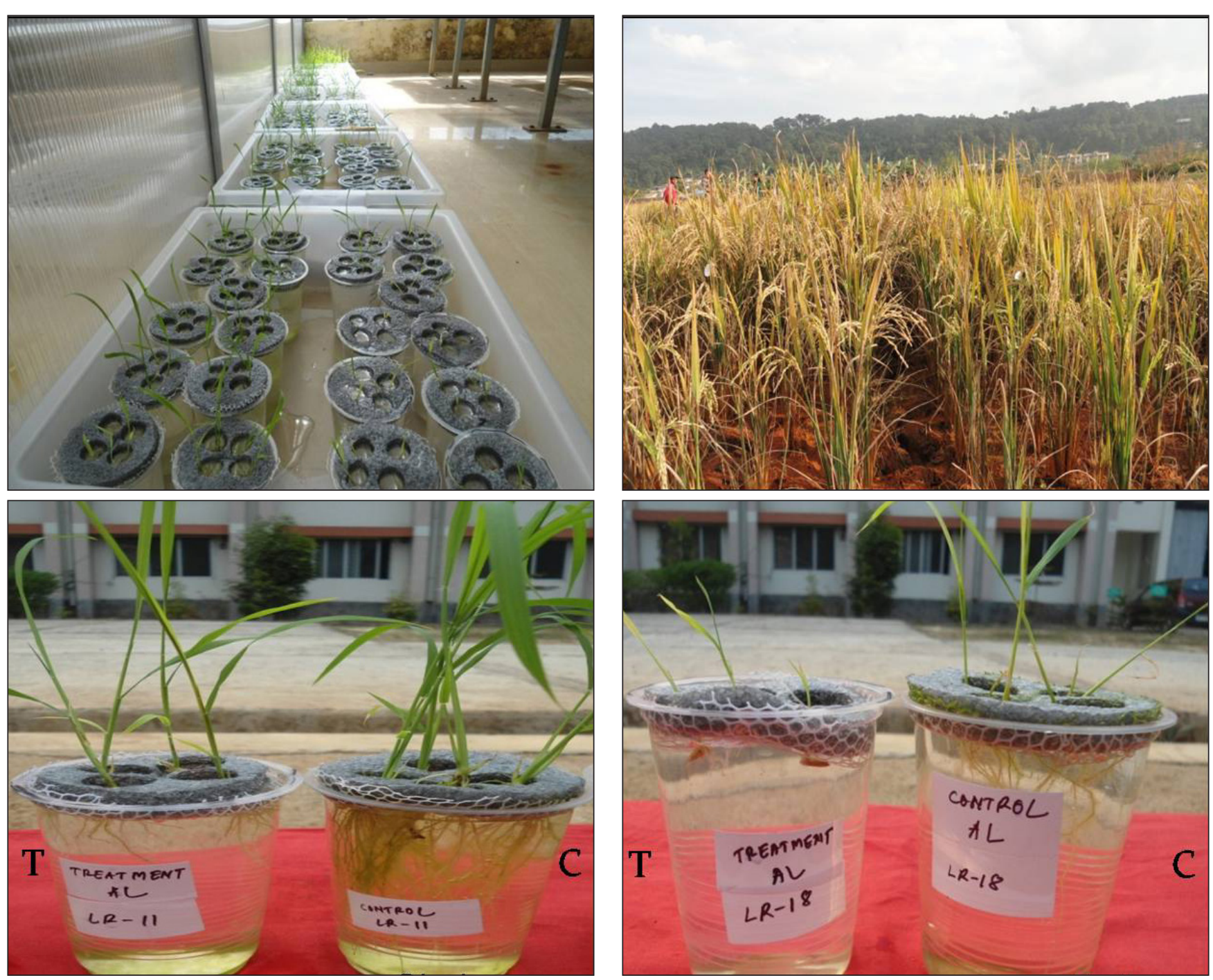

Figure 1: Growth of parents and crosses in field condition aling with hydroponics experimental set up for aluminium toxicity screening in green house; C: Control (0 M Al); T: Treatment (540 $\mu \mathrm{M}$ Al)
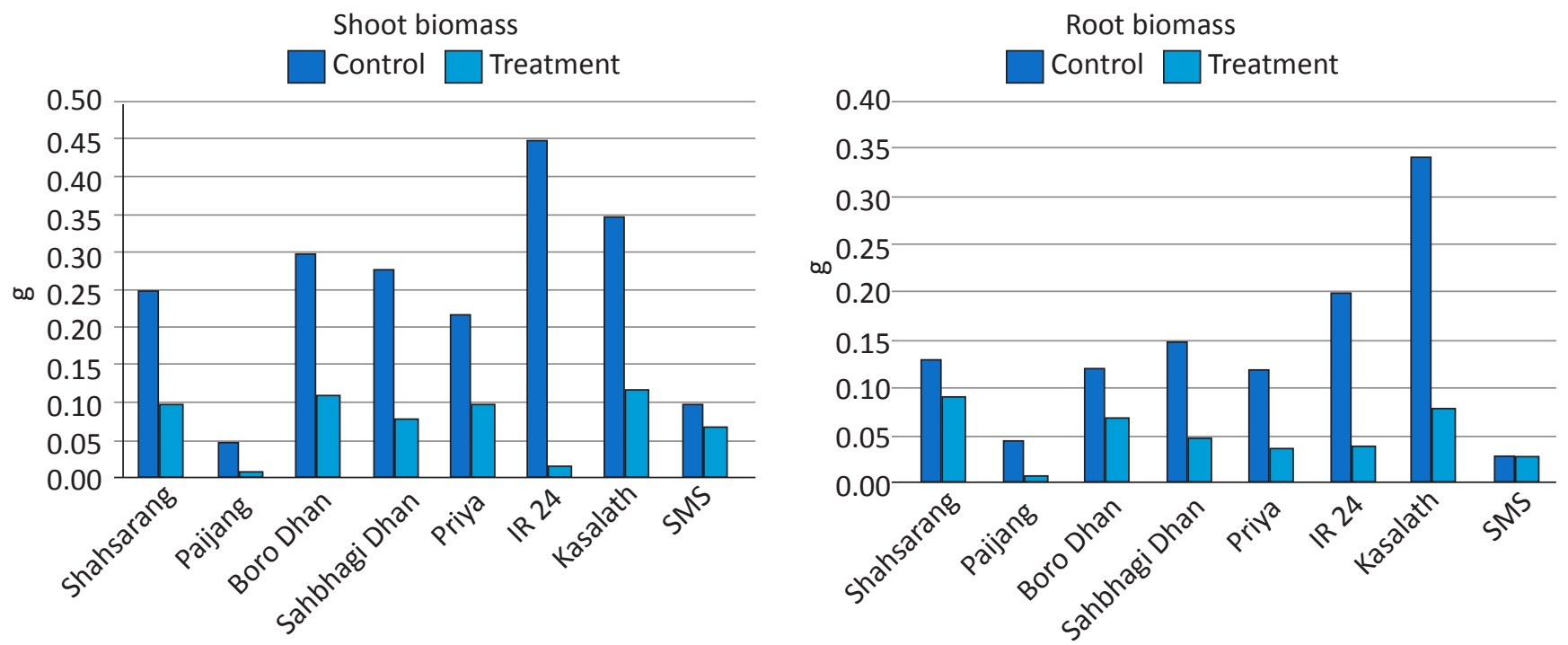

Figure 2: Variation in shoot and root biomass among parents under control (0 M Al) and (540 $\mu \mathrm{M} \mathrm{Al})$ hydroponics conditions 

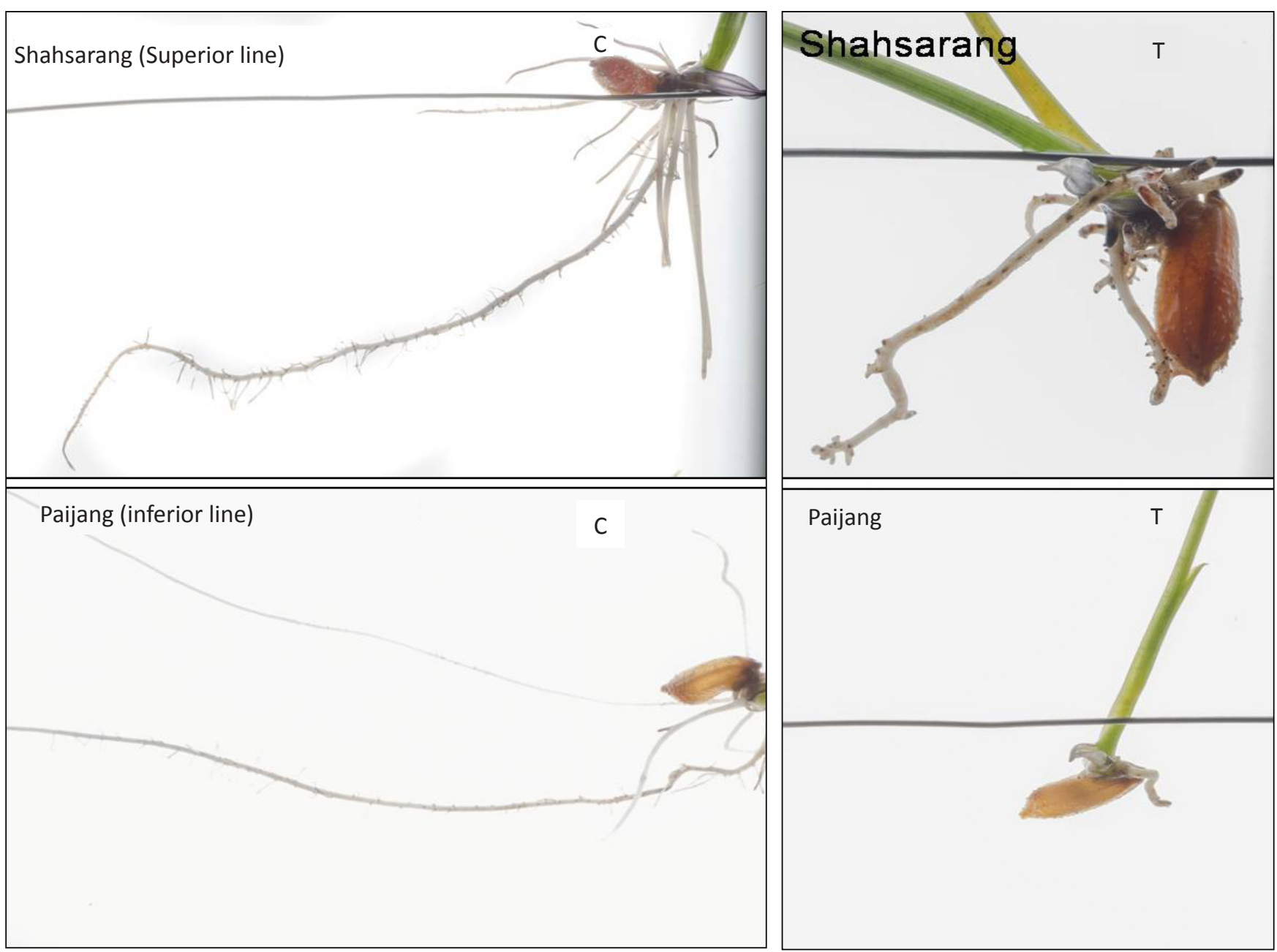

Figure 3: Effect of aluminium toxicity on rice roots in hydroponics conditions. C: Control (0 M Al); T: Treatment (540 $\mu \mathrm{M}$ Al)

sorghum. As Al tolerance is a quantitative trait, it is possible different mechanisms work in different genetic backgrounds. In our experiment, same conditions as previously reported by Famoso et al. (2010) were used to screen 8 parents. As the initial and most dramatic affect of Al toxicity is on the root system architecture, the inhibition of root elongation, development of root hair and callose deposition were the key traits focused during screening. Root growth inhibition was seen in the treatment conditions for all the rice genotypes. However, the severity depended upon their degree of tolerance.

\section{Conclusion}

The GCA and SCA, including heterosis is helpful in finding the best cross combination for varietal developmental programmes. Heterosis was observed in most of the $F_{1} s$. The $\mathrm{F}_{1} \mathrm{~s}$ of the cross Sahbhagi Dhan $\times$ Kasalath and PriyaxIR 24 showing high SCA value can be used for hybrid production. Transgressive segregants from Sahbhagi DhanxKasalath cross can be selected as both the parents showed good GCA. The parents performing well in aluminium toxic hydroponic condition can be used for future breeding programmes.

\section{References}

Bagheri, N., Jelodar, N.B., 2010. Heterosis and combining ability analysis for yield andrelated-yield traits in hybrid rice. International Journal of Biology 2, 222-231.

Famoso, A.N., Clark, R.T., Shaff, J.E., Craft, E., McCouch, S.R., Kochian, L.V., 2010. Development of a novel aluminum tolerance phenotyping platform used for comparisons of cereal aluminum tolerance and investigations into rice aluminum tolerance mechanisms. Plant Physiology 153, 1678-1691.

Hasan, M.J., Kulsum, U.K., Lipi. L.F., Shamsuddin, A.K.M., 2013. Combining ability studies for developing new rice hybrids in Bangladesh. Bangladesh Journal of Botany 42, 215-222.

Jones, J.W., 1926. Hybrid vigour in rice. American society of Agronomy 18, 423-428.

Kochian, L.V., 1995. Cellular mechanisms of aluminum toxicity and resistance in plants. Annual Review of Plant 
Physiology and Plant Molecular Biology 46, 237-260.

Kochian, L.V., Hoekenga, O.A., Pineros, M.A., 2004. How do crop plants tolerate acid soils? Mechanisms of aluminum tolerance and phosphorous efficiency. Annual Review of Plant Biology 55, 459-493.

Maclean, J.L., Dawe, D.C., Hard, Y.B., Hettel, G.P., 2002. Rice Almanac, $3^{\text {rd }}$ edn. IRRI,Manila.

Magnavaca, R., Gardner, C.O., Clark, R.B., 1987. Evaluation of inbred maize lines for aluminium tolerance in nutrient solution. Genetic Aspects of Plant Mineral Nutrition Martinus Nijhoff, Dordrecht, Netherlands, 255-265.

Mandal, S.C., 1997. Introduction and historical overview. In Acidic Soils of India (eds. Mahapatra, I.C. et al.), ICAR, New Delhi, 3-24.

Muhammad, R., Cheema, A.A., Ashraf, M., 2007. LinexTester analysis in basmati rice. Pakistan Journal of Botany 39, 2035-2042.

Nuruzzaman, M., Alam, M.F., Ahmad, G.M., Shoahel, A.M.,
Biswas, M.K., Amin, R.M., Hossain, M.M., 2002. Studies on parental variability and heterosis in rice. Pakistan Journal of Botany 5, 1006-1009.

Rahimi, M., Rabiei, B., Samizadeh, H., Ghasemi, A.K., 2010. Combining ability and heterosis in rice (Oryza sativa L.) cultivars. Journal of Agricultural Science and Technology $12,223-231$.

Sharma, U.C., Singh, R.P., 2002. Acid soils of India: their distribution, management and future strategies for higher productivity, Fertilizer News 47, 45-52.

Singh, N.K., Kumar, A., 2004. Combining ability analysis to identify suitable parents for heterotic rice hybrid breeding. IRRN 29, 21-22.

Zhang, R., Ming, J.S., Xu, C.W., Yang, L.S., Bai, Y.S., Sun, C.Q., Wanc, X.K., 2002. Heterosis and combining ability of hybrid rice and its relation to Japonica-Indica index of parents. Rice Genetics Newsletter 14, 34. 